\title{
Analisis Tarif Rumah Sakit Terhadap Kualitas Pelayana Pasien Umum dan Pasien BPJS di Rumah Sakit Muhammadiyah Ahmad Dahlan Kota Kediri
}

\author{
Yohana Nilasari ${ }^{1}$, Arisyahidin ${ }^{2}$, Eka Askafi $^{3}$ \\ ${ }^{1}$ Rumah Sakit Muhammadiyah Ahmad Dahlan Kota Kediri \\ 2,3Magister Managemen Universitas Islam Kadiri \\ 1Email: yohanna.hussein@gmail.com
}

\begin{abstract}
The hospital of Mubammadiyah Abmad Dablan Kediri is a place that gives the service to individual's health with hospitalized service, regular service and emergency service. The Hospital of Muhammadiyah Ahmad Dablan Kediri is a hospital with class C that has capacity 205 beds. Bed Occupational Rate (BOR) for 4 years lately is around 52,5\%. The operational expense of hospital is totally from the patients so that the position of customer is very important.

This research Design Uses Correlational Analysis Survey Design by approaching Cross Sectional. It uses the population of all for long hospitalized patients that had got service in Hospital of Muhammadiyah Ahmad Dablan Kediri, and their number is 125 patients with 55 patients as the sample, it is taken by using the technique of purposive sampling. The collection of Data uses the questioner. The data of Research was analyzed by Moderated Regression Analysis Test.

there are 3 variables that become research material, from the 3 variables studied, there are a total of 23 question items. From each question item, both independent and dependent, it turned out to have a correlation probability value below 0.005 or the Service research variable data (X), General patient satisfaction (Y1) and BPJS patient satisfaction (Y2) at Muhammadiyah Ahmad Dablan Hospital, Kediri City were declared valid. . From the results of the questionnaire obtained after being processed, it can be seen from the highest average value obtained in empathy from service providers, which is 3.69 which means the attitude of nurses and doctors is good when responding to questions from patients' families and hospital visitors. While the lowest average is 2.85 , which is from the time of the doctor's examination according to the schedule. This explains that many patients are dissatisfied with the doctor's schedule for not being on time.

Conclution: There are two kinds of service rates at the Mubammadiyah Abmad Dablan Hospital, Kediri City, which results in differences in treatment for general patients and BPJS patients who seek treatment at Muhammadiyah Ahmad Dablan Hospital, Kediri City. There is an effect of service rates on general patient satisfaction and BPJS patients at home. Muhammadiyah Hospital Ahmad Dablan, Kediri City. Although there are differences in treatment and service, there are differences in satisfaction between general patients and BPJS patients at the Muhammadiah Ahmad Hospital. Dablan, Kediri. Not too significant.

Keywords: service rates, patient satisfaction
\end{abstract}

\section{Latar Belakang Teoritis}

Potter \& Perry (2007), menyatakan bahwa pengguna pelayanan kesehatan sekarang sudah memiliki pengetahuan dan perhatian yang cukup baik terhadap isu kesehatan dan juga tentang kualitas keperawatan, rumah sakit dan dokter. Pengalaman pasien menggunakan pelayanan kesehatan merupakan tolak ukuran kualitas suatu rumah sakit, walaupun rumah sakit tersebut memiliki tingkat teknologi yang tinggi.

Cara pandang masyarakat terhadap penilaian dan pemilihan pelayanan kesehatan berubah karena persaingan bisnis rumah sakit yang sangat kompetitif. Rumah Sakit dituntut untuk lebih memperhatikan kepuasan pasien dan peningkatan mutu pelayanan baik pasien rawat inap maupun rawat jalan. Oleh karena itu Rumah Sakit harus meningkatkan kualitas pelayanannya dengan memanfaatkan sumber daya yang ada. Seiring waktu rumah sakit yang tidak berkualitas akan tergerus oleh persaingan bisnis rumah sakit yang sangat sengit (Gultom, Jenny, 2008). Konsep SerQual yang digunakan dalam penilaian pelayanan kesehatan menurut Parasuraman (1990) adalah: reliability, responsiveness, assurance, empatby, tangibles. Indonesia melaksanakannya melalui program Jaminan Kesehatan atau Jaminan Kesehatan Nasional (JKN). Program JKN dimulai dengan diberlakukannya 
undang-Undang Nomor 40 Tahun 2004 tentang Sistem Jaminan Sosial Nasional (UU SJSN) dan Undang-Undang Nomor 24 Tahun 2011 tentang Badan Penyelenggara Jaminan Sosial (UU BPJS) (Thabrany, 2014). Selain itu, cakupan kesehatan semesta diwujudkan dengan visi Indonesia sehat 2020 yang dibangun atas dasar 3 (tiga) pilar, yaitu lingkungan sehat, perilaku sehat, dan pelayanan kesehatan yang bermutu, adil, merata, dan terjangkau oleh seluruh masyarakat (Sulaeman, 2014). Untuk tarif yang berlaku pada 1 Januari 2014, telah dilakukan penyesuaian dari tarif Indonesian Case Based Groups (INA-CBG's) Jamkesmas dan telah ditetapkan dalam Peraturan Menteri Kesehatan nomor 59 tahun 2014 tentang standar tarif pelayanan kesehatan pada fasilitas kesehatan tingkat pertama dan fasilitas kesehatan tingkat lanjutan dalam penyelenggaraan jaminan kesehatan (DEPKES RI, 2014).

JKN adalah suatu bentuk jaminan untuk menjamin kesehatan yang bermanfaat sebagai perlindungan dan pemeliharaan kesehatan yang diperoleh dengan cara membayar iuran.

Perbedaan Tarif Layanan Rawat Jalan Tanpa Tindakan Rumah Sakit Muhammadiyah Ahmad Dahlan Kota Kediri dengan Tarif Paket INA- CBG's dari BPJS

\begin{tabular}{|l|l|l|}
\hline Pelayanan & $\begin{array}{c}\text { Tarif INA } \\
\text { CBG's }\end{array}$ & Tarif RS \\
\hline $\begin{array}{l}\text { Spesialis } \\
\text { Jantung }\end{array}$ & Rp190,400 & Rp178,800 \\
\hline THT & Rp190,400 & Rp136,200 \\
\hline $\begin{array}{l}\text { Spesialis } \\
\text { Urologi }\end{array}$ & Rp190,400 & Rp186,100 \\
\hline Spesialis Mata & Rp190,400 & Rp158,800 \\
\hline $\begin{array}{l}\text { Spesialis } \\
\text { Ortopedi }\end{array}$ & Rp190,400 & Rp179,000 \\
\hline $\begin{array}{l}\text { Spesialis Bedah } \\
\text { Umum }\end{array}$ & Rp190,400 & Rp125,000 \\
\hline Sp. Rehab & Rp112,800 & Rp125,000 \\
\hline
\end{tabular}

\begin{tabular}{|l|l|l|} 
Medik & & \\
\hline Sp, Kandungan & Rp190,400 & Rp160,700 \\
\hline $\begin{array}{l}\text { Sp. Penyakit } \\
\text { Dalam }\end{array}$ & Rp190,400 & Rp143,200 \\
\hline Dr Umum & Rp190,400 & Rp131,700 \\
\hline HD & Rp825,500 & Rp850,000 \\
\hline Sp. Anak & Rp190,400 & Rp149,000 \\
\hline Sp. Syaraf & Rp190,400 & Rp108,000 \\
\hline Sp. Paru & Rp190,400 & Rp102,100 \\
\hline
\end{tabular}

Sumber: Data dari Unit Rekam Medis RSM Abmad DablanKota Kediri 2020 yang diolah

Dari Tabel 1.1 diatas merupakan daftar tarif layanan Rawat Jalan di Rumah Sakit Muhammadiyah Ahmad Dahlan Kota Kediri tanpa ada tindakan tambahan atau Khusus, atau merupakan Tarif layanan dasar. Dari daftar diatas, dapat disimpulkan bahwa pada dasarnya masih ada selisih lebih bagi Rumah Sakit terhadap tarif INA CBG's. akan tetapi jika dalam pelaksanaan pemeriksaan, pasien memerlukan perawatan tambahan maka akan memunculkan selisih negatif tarif layanannya, karena tarif paket dari BPJS tidak berubah, tarif Rumah Sakit berubah mengikuti layanan yang diberikan kepada pasien. Sejak pelaksanaan Jaminan Kesehatan Nasional (JKN), banyak permasalahan yang harus dihadapi. Masyarakat mengeluhkan sulitnya mendapatkan pelayanan yang memadai. Pada saat akan melakukan pemeriksaan penunjang baik pemeriksaan laboratorium maupun radiologi kadang harus datang beberapa kali dikarenakan jatah biaya sudah melampaui paket INA- CBG's. Tidak jarang terlihat pasien komplain pada saat mengambil obat di apotik yang disebabkan oleh obat yang tidak tersedia (kosong) ataupun jumlah obat yang diterima dirasakan pasien kurang. Dipihak lain, banyak rumah sakit yang mengeluh dengan besaran tarif pembiayaan yang diatur dalam Permenkes No 59 tahun 2014. Besaran tarif dalam peraturan tersebut dianggap terlalu kecil dan tidak sesuai dengan jasa medis, harga obat 
dan reagen atau bahan habis pakai terkini. Akibatnya dari sudut pandang pasien, timbul kesan bahwa pihak rumah sakit hanya memberikan pelayanan seadanya yang disertai ketidak ramahan dari petugas kesehatan. Sejak adanya JKN di Rumas Sakit Muhammadiyah Ahmad Dahlan Kota Kediri pada pertengahan tahun 2014, terjadi lonjakan kunjungan pasien terutama pasien rawat jalan. Dalam penelitian ini peneliti menampilkan kunjungan pasien pada tahun 2020, dimana pasien mengalami penurunan sebagai dampak dari pandemi akibat Covid19. dan dari tabel 1.2 diatas dapat kita lihat bahwa penerimaan retribusi pada semester pertama di Rumah Sakit Muhammadiyah Ahmad Dahlan Kota Kediri, sebagian besar masih pada layanan Rawat Inapnya. Sebelum masa pandemi, jumlah retribusi pendapatan Rumah Sakit Muhammadiyah Ahmad Dahlan Kota Kediri memang mengalami penurunan setiap bulan februari setiap tahunnya karena jumlah hari yang pendek, tetapi bulan dan seterusnya akan mengalami kenaikan yang signifikan. Akan tetapi hal tersebut tidak berlaku untuk tahun 2020 ini. Karena jika dilihat dari tabel yang penulis tampilkan dapat disimpulkan bahwa retribusi untuk pasien BPJS khususnya Rawat Jalan mengalami penurunan yang sangat signifikan dari bulan ke bulan.

Penurunan ini ada beberapa penyebab antara lain adalah salah satu dampak dari pandemi yang sedang terjadi di seluruh dunia. Dan ini mengakibatnya banyak pasien JKN yang biaya perawatannya berpindah pertanggungan dari BPJS ke KEMENKES RI karena indikasi yang diderita pasien mengarah ke Covid-19. Selain itu penurunan terjadi karena efek pembatasan jumlah pasien yang berobat di Rumah Sakit Muhammadiyah Ahmad Dahlan Kota Kediri. Hal ini dilakukan manajemen Rumah Sakit Muhammadiyah Ahmad Dahlan Kota Kediri untuk membantu menekan penyebaran Virus Covid-19. Dan penurunan tingkat kunjungan pasien itu sangat berpengaruh terhadap kinerja pelayanan di Rumah Sakit Muhammadiyah Ahmad Dahlan Kota Kediri. Sehingga jika dilihat dari indikatornya, kinerja di Rumah Sakit Muhammadiyah Ahmad Dahlan Kota Kediri masih dibawah nilai ideal dari standart yang diberikan Pemerintah. Tarif rumah sakit merupakan aspek yang sangat diperhatikan oleh rumah sakit swasta juga oleh rumah sakit milik pemerintah. (Trisnantoro, 2009). Akan tetapi Biaya pembayaran paket dari BPJS seringkali terdapat selisih antara tarif paket dan tarif riil (Wijayanti, 2010). Perbedaan tarif yang ada di Rumah Sakit dapat berdampak pada pelayanan terhadap pasien. Hal tersebut membuat Rumah Sakit menggolongkan pasien menjadi dua jenis yaitu pasien umum dan pasien BPJS. Dimana pasien umum itu termasuk didalamnya ada pasien Asuransi dan Jamkesda. Dari kenyataan yang terjadi itu maka peneliti ingin mengeta hubungan tarif pelayanan dengan kepuasan pasien Umum dan BPJS.

Menurut teori Dunn (1994), terdapat tiga elemen sistem kebijakan, yaitu: pelaku kebijakan, lingkungan kebijakan dan kebijakan publik. Pengalaman banyak negara menunjukkan bahwa peranan masyarakat dalam bentuk upaya kegotongroyongan dalam mengatasi pembiayaan kesehatan memiliki peran penting. Bentuk kegotong - royongan masyarakat itu, diperkenalkan sebagai program

asuransi kesehatan (Sulastomo, 2007).Amandemen UUD 1945 pada tahun 2000 telah memasukkan kata-kata "kesehatan".

\begin{tabular}{rcrr}
\multicolumn{2}{c}{ Pencantuman } & hak & terhadap \\
pelayanan kesehatan & bertujuan & untuk \\
menjamin & hak-hak & kesehatan & yang
\end{tabular} fundamental. Dan pada amandemen UUD 1945 tanggal 11 Agustus 2002 MPR telah mengamanatkan agar Negara mengembangkan jaminan sosial bagi seluruh rakyat seperti tercantum pada Pasal 34 ayat 2 UUD 1945. Dengan adanya amandemen tersebut tujuan negara sudah semakin jelas, yaitu secara eksplisit menempatkan kesehatan sebagai bagian dari kesejahteraan rakyat yang harus tersedia merata (Adisasmito, 2007).

\section{Metode penelitian}

Parasuraman, et al., (1988:118) menyusun dimensi pokok yang menjadi faktor utama penentu kualitas layanan jasa sebagai berikut:

1. Reliability (Keandalan). Yaitu kemampuan untuk mewujudkan pelayanan yang dijanjikan dengan handal dan akurat. Maksudn pya 
adalah Rumah sakit mampu memberikan pelayanan kesehatan sesuai dengan apa yang telah distandartkan pemerintah. Yaitu sesuai dengan kriteria Akreditasi Rumah Sakit.

2. Responsiveness (Daya tanggap). Yaitu kemauan untuk membantu para konsumen dengan menyediakan pelayanan yang cepat dan tepat. Yang dimaksud disini adalah kecepatan dan ketepatan pelayanan sesuai dengan kriteria dan kedaruratan pasien yang datang ke rumah sakit. Biasanya ada beberapa kode warna seperti merah untuk gawat darurat maka harus ditangani paling dahulu, warna kuning untuk pasien tingkat kegawatan lebih rendah akan ditangani setelah pasien kode merah, warna hijau untuk pasien yang masih bisa menunggu layanan.

3. Assurance (Jaminan). Yaitu meliputi pengetahuan, kemampuan, dan kesopanan atau kebaikan dari personal serta kemampuan untuk mendapatkan kepercayaan dan keinginan. Yang dimaksud jaminan adalah kemampuan tenaga kesehatan yang ada di rumah sakit merupakan tenaga kesehatan yang handal atau sudah berpenngalaman dibidangnya, sehingga pasien akan merasa lebih tenang dan yakin dalam menjalani proses pengobatan

4. Empathy (Empati). Yaitu mencakup menjaga dan memberikan tingkat perhatian secara individu atau pribadi terhadap kebutuhan-kebutuhan konsumen. Dalam hal ini rumah sakit harus lebih tanggap dalam menghadapi segala macam pasien yang datang berobat. Dan rumah sakit dapat memberikan perhatian lebih misalkan dengan memberikan souvenir atau produk khusus untuk pasien yang berobat sehingga pasien merasa lebih diperhatikan. Seperti yang dilakukan di Rumah Sakit Muhammadiyah Ahmad Dahlan Kota Kediri yaitu memberikan layanan pengantaran pulang bagi pasien secara gratis.

5. Tangible (Bukti langsung). Yaitu meliputi fasilitas fisik, peralatan atau perlengkapan, harga, dan penampilan personal dan material tertulis. Seperti di Rumah Sakit Muhammadiyah Ahmad Dahlan Kota Kediri, fasilitas yang terlihat antara lain gedung, peralatan medis yang lengkap, juga karyawan yang menggunakan seragam yang berbeda dari rumah sakit lain, sehingga membuat suasana rumah sakit menjadi berbeda dengan rumah sakit yang lainnya.
Pasien adalah orang yang memiliki kelemahan fisik atau mentalnya menyerahkan pengawasan dan perawatannya, menerima dan mengikuti pengobatan yang ditetapkan oleh tenaga kesehatan yang dikemukakan oleh Prabowo (dalam Wilhamda, 2011). Sedangkan (Aditama, 2002) berpendapat bahwa pasien adalah mereka yang diobati dirumah sakit. Menurut (Soejadi, 1996) pasien adalah individu terpenting dirumah sakit. Pada dasarnya pasien umum maupun bpjs adalah sama dalam hal pengertian maupun hak dan kewajibannya. pasien umum adalah pasien yang menggunakan fasilitas kesehatan dan membayar layanannya secara langsung maupun Asuransi umum. Sedangkan pasien bpjs adalah pasian yang menggunakan fasilitas pelayanan dimana pembayarannya dilakukan melalui instansi BPJS Kesehatan. Terkadang adanya perbedaan dalam pelayanan dipengaruhi dari cara pembayaran pasien itu sendiri. Karena pada dasarnya ada perbedaan dalam waktu pembayaran seperti yang terjadi pada pasien BPJS yang mana tagihan pembayarannya akan mengalami penundaan beberapa bulan kedepannya. Sehingga dapat mempengaruhi biaya operasional yang dibutuhkan oleh rumah sakit terutam rumah sakit swasta yang semua biayanya ditanggung oleh perusahaan itu sendiri. Jenis penelitian ini adalah deskriptif korelasional dengan pendekatan kuantitatif. Sugiyono menyatakan bahwa penelitian deskriptif korelasional bertujuan mendeskripsikan atau memberikan gambaran hubungan terhadap dua variabel melalui data sampel dalam suatu populasi sebagaimana adanya . Dalam hal ini, peneliti ingin melihat hubungan antara variabel $\mathrm{X}$ dengan $\mathrm{Y} 1$ dan $\mathrm{Y} 2$, yaitu hubungan antara tarif pelayanan $(\mathrm{X})$ dan dengan variabel kepuasan pasien Umum (Y1) dan pasien BPJS (Y2).

Pendekatan kuantitatif menurut Arikunto yaitu, penelitian yang banyak dituntut meggunakan angka, mulai dari pengumpulan data, penafsiran data serta penyajian hasil penelitian. Penelitian dilakukan di Rumah sakit Muhammadiyah Ahmad Dahlan Jl. Gatot Subroto No. 84 Mojoroto Kota Kediri. Dimana dirumah sakit ini ada dua macam penggolongan pasien yaitu pasien umum dan pasien BPJS. Populasi sampling yang digunakan oleh peneliti yaitu Unit Rawat Jalan terdiri dari pasien dan 
karyawan dari unit rawat jalan, Unit Rekam Medis sebagai bagian yang mengolah data pasien, dan Bagian Casemix pada Rumah Sakit Muhammadiyah Ahmad Dahlan Kota Kediri sebagai bagian yang melakukan proses data dari unit Rawat jalan untuk keperluan Klaim BPJS. Populasi dalam penlitian ini adalah semua pasien lama dan baru rawat jalan yang telah mendapatkan pelayanan medis dan non medis di instalasi rawat jalan Rumah Sakit Muhammadiyah Ahmad Dahlan Kota Kediri. Jumlah populasi yang akan dilakukan dalam penelitian ini adalah 55 pasien Umum dan 55 Pasien BPJS. Pengambilan sampel dilakukan dengan teknik insidental , menurut Sugiono (2011:85), bahwa sampling insidental adalah penentuan sampel berdasarkan kebetulan ,yaitu siapa saja yang secara kebetulan/ insidental bertemu dengan peneliti maka dapat digunakan sebagai sampel, apabila orang tersebut dipandang cocok sebagai sumber data.

\section{Hasil Penelitian Dan Pembahasan}

terdapat 3 variabel yang menjadi bahan penelitian, dari ke 3 variabel yang diteliti tersebut memiliki item pertanyaan total sebanyak 23 item pertanyaan. Dari masing-masing item pertanyaan baik independen maupun dependen ternyata memikili nilai probabilitas korelasi dibawah 0,005 atau data Variabel penelitian Pelayanan $(\mathrm{X})$, Kepuasan pasien umum (Y1) dan Kepuasan pasien BPJS (Y2) di Rumah Sakit Muhammadiyah Ahmad Dahlan Kota Kediri di nyatakan valid.

Berdasarkan tabel tersebut diatas menunjukkan bahwa pengujian ini dilakukan secara variabel bukan secara item pertanyaan pada setiap variabel yang dapat dilihat hasilnya adalah nilai cronbah's alpha lebih besar dari pada 0,6 sehingga bisa dikatakan realiabel.

Nilai yang dihasilkan pada Asym.sig untuk variabel tarif layanan sebesar 0,2, variabel kepuasan pasien umum 0,077 dan variabel kepuasan pasien bpjs sebesar 0,71 sehingga dapat di katakan bahwa nilai asymp.sig dari semua data berdistribusi normal karena nilainya lebih dari 0,05 semua. nilai $F=11,222$ dengan tingkat signifikan 0,001. Tingkat signifikan akan dibandingkan dengan 0,05 (karena menggunakan taraf signifikan taraf segnifikan atau $\alpha=5 \%$ ). $0.001<0.05$ Tidak ada hubungan yang liniear antara Tarif pelayanan dan Kepuasan Pasien nilai $F=14,815$ dengan tingkat signifikan 0,000 . Tingkat signifikan akan dibandingkan dengan 0,05 Karena 0.000 $<0.05$ maka Tidak ada hubungan yang liniear antara Tarif pelayanan dan Kepuasan Pasien Dari hasil pengujian multikolinearitas dapat dilihat bahwa tarif pelayanan memiliki nilai tolerance sebesar 1,000. Nilai VIF Kepuasan pasien umum sebesar 1,000. Nilai VIF variabel tersebut $<10$. Sehingga dapat disimpulkan tidak terjadi multikolinearitas, karena berdasarkan variabel bebas memiliki nilai tolerance $>0.10$

Berdasarkan hasil pengujian persyaratan analisis statistik Dalam penelitian ini, Terdapat perngaruh positif dan signifikan antara pelayanan yang terdiri dari bukti Langsung (Tangibles), keandalan (reliability), daya tanggap (reponsiveness), jaminan (assurance), dan empati (Amphaty) terhadap kepuasan pasien umum maupun BPJS sebagai pengguna layanan kesehatan Ada perbedaan pelayanan yang diberikan kepada pasien umum dan pasien bpjs. Seperti ada beberapa obat yang tidak ditanggung bpjs sehingga tidak diberikan kepada pasien bpjs juga fasilitas pengantaran pulang secara gratis bagi pasien rawat inap yang tidak didapatkan oleh pasien bpjs.

Pengaruh yang ditimbulkan dari perbedaan tarif layanan antara pasien BPJS dan pasien Umum tidak terlalu significant. Karena pasien BPJS merasa cukup terlayani dengan apa yang diberikan oleh Rumah sakit.

Karateristik responden yang dilakukan berdasarkan hasil kuisioner didapatkan data sebagai berikut. Dari pertanyaan mengenai pelayanan yang didapat terkait dengan tarif yang mengikutinya, nilai yang didapat adalah nilai tengah atau antara 3 - 4. yang berarti jawaban dari responden terkait pelayanan yang diberikan adalah seimbang antara yang merasa puas dan tidak. Dari sini dapat disimpulkan bahwa pelayanan yang diberikan belum sesuai dengan apa yang disampaikan dalam teori teori yang menyatakan bahwa pelayanan merupakan service excelent. Seperti kondisi ruangan yang bersih dan nyaman, $50 \%$ dari responden menyatakan setuju sedangkan $50 \%$ yang lain menyatakan netral . karena itu untuk kebersihan harus harus ditingkatkan agar 
semua pasien merasa bahwa Rumah Sakit Muhammadiah Ahmad Dahlan Kota Kediri bersih dan rapi. Pada butir penmpilan dokter dan perawat yang bersih dan rapi, hanya 18\% yang menjawab sangat setuju. Untuk jawaban yang mendapatkan nilai 4 dari kuisioner selanjutnya adalah pada point tanggapan dokter pada keluhan pasien $9 \%$, sikap perawat kepada keluarga pasien 13\%, dan ketelitian dokter pada saat pemeriksaan pasien $9 \%$. dari prosentase prosentase tersebut dapat disimpulkan bahwa harus ada perhatian khusus dalam meninggkatkan pelayanan kepada pasien di Rumah Sakit Muhammadiah Ahmad Dahlan Kota Kediri. Kurangnya pelayanan yang diberikan kepada pasien tersebut terpengaruh dari nilai tarif yang berbeda antara tarif layanan pasien Umum dan tarif layanan pasien BPJS. Dan perbedaan tersebut mempengaruhi nilai jasa pelayanan yang diterima oleh karyawan. Dan hal tersebut yang akhirnya berimbas kepada pelayanan yang diberikan kepada pasien.

Pengaruh Kualitas Pelayanan terhadap kepuasan pasien Umum dan BPJS.

Dari hasil analisis regresi linear didapat nilai $\mathrm{p}$ value $=0,001$ untuk pasien umum dan 0,000 untuk pasien bpjs. Hal ini menyatakan bahwa adnya pengaruh antara pelayanan dengan kepuasan pasien.

Kualitas layanan sangatlah krusial bagi perusahaan. Secara sedehana, kualitas layanan dapat diartikan sebagai ukuran seberapa bagus tingkat pelayanan yang diberikan mampu sesuai dengan ekspektasi pelanggan (lewis \& Broom,1983 dalam Tjiptono,2011). Dalam hal ini kualitas pelayanan di rumah sakit, berbagai aspek kualitas yang diharapkan dari pasien pada hasil penelitian ini.seperti Indikator bukti langsung (tangible), Keandalan (reliability), daya Tanggap ( responsiveness), Jaminan (assurance), Empati (Amphaty)

(Parasuratman, et al., 1985)

Jika beberapa hal ini terpenuhi maka akan timbul rasa ketergantungan pasien sehingga jika suatu saat membutuhkan pelayanan kesehatan maka yang terbersit dalam ingatannya adalah Rumah Sakit Muhammadiah Ahmad Dahlan Kota Kediri.

Dari penelitian yang dilakukan ternyata untuk pasien umum maupun pasian BPJS tingkat kepuasan yang dirasakan pasien idak terlalu berbeda mesipun pada kenyataannya ada perbedaan perlakuan dalam pelayanan.

\section{Kesimpulan}

Berdasarkan hasil penelitian tentang Pengaruh tarif pelayanan terhadap kepuasann pasien umum dan bpjs di Rumah Sakit Muhammadiah Ahmad Dahlan Kota Kediri. Dapat disimpulkan:

Ada dua macam tarif layanan di Rumah Sakit Muhammadiyah Ahmad Dahlan Kota Kediri, yang mengakibatkan perbedaan perlakuan terhadap pasien umum dan pasien bpjs yang berobat di Rumah Sakit Muhammadiyah Ahmad Dahlan Kota Kediri

Ada pengaruh tarif pelayanan terhadap kepuasan pasien Umum dan pasien BPJS di Rumah Sakit Muhammadiah Ahmad Dahlan Kota Kediri.

Meskipun ada pebedaan perlakuan dan pelayanan tetapi perbedaan kepuaasan antar pasien umum dan pasien bpjs di Rumah Sakit Muhammadiah Ahmad. Dahlan Kota Kediri. Tidak terlalu significant.

Saran yang dapat penelitiberikan Bagi pihak Rumah Sakit Muhammadiyah Ahmad Dahlan Kota Kediri adalah, Karena kepuasann pasien sangat penting dalam suatu perusahaan apapun sehingga bisa mempengaruhi keloyalan daripada pasien itu sendiri maka, Rumah Sakit Muhammadiyah Ahmad Dahlan Kota Kediri harus meningkatkan pelayanannya dengan menerapkan service excelent tanpa membedakaan status pasien yang ada. sehingga terbentuk pasien yang loyal kepada Rumah Sakit Muhammadiyah Ahmad Dahlan Kota Kediri itu sendiri.

secara teoritis, penulis memberi saran sebagai berikut:

Bagi peneliti selanjutnya diharapkan untuk mengembangkan hasil penelitian ini dengan mengkaji atau menambahkan subjek penelitian, variabel penelitian dan metode penelitian sebagai alat pengukurannya..

Keterbatasan yang peneliti alami adalah Pengumpulan data yang dilakukan membutuhkan waktu yang agak panjang karena tidak semua responden memenuhi kriteria, dan bersedia menjadi responden Karena penelitian ini jenis kuantitatif dan metode pengambilan data secara sampling pada waktu tertentu maka gambaran kodisi selanjutnya tidak diketahui Peneliti 
membatasi variabel yang diteliti padahal ada banyak variabel yang bisa mempengaruhi kepuasan pasien.

\section{Daftar Pustaka}

Gultom, Jenny (2008). Analisis Kepuasan Pasien terbadap Pelayanan Rawat Jalan di Poliklinik Rumah Sakit Azra Tabun 2008 Parasuraman, A., Zeithml, V.A., Beny, L.L (1990). Delivery Quality Service: Balancing Costumer Perception and Expectation. New York: The Press.

Potter, AP \& Perry, GA. (2007). Fundamental of Nursing: Concept, Proccess \& Practice. St Louis: Mosby Year Book.

Satrianegara MF, S.S. (2009), Buku Ajar Organisasi dan Manajemen Pelayanan Kesehatan Serta Kebidanan. Salemba Medika. Jakarta.

Tjiptono, F. (2008). Servive Management Mewujudkan Layanan Prima. Yogyakarta: Andi

Ile I dan Garr E. 2011. Financing health care and policy issues in developing countries: decision making in ghana'? $s$ bealth insurance policy process. African Journal of Business Management. Vol 6(6):2375-2383. DOI 10.5897/AJBM11.172

Thabrany H .2014. Jaminan kesehatan nasional. Jakarta. Raja Grafindo Persada.

Sulastomo. 2007. Manajemen kesehatan. Jakarta. Gramedia Pustaka Utama.

Adisasmito W. 2010. Sistem kesehatan. Jakarta . Rajawali Press.

Ambarriani AS. 2014. Hospital financial performance in the indonesian national bealth insurance era. Review of Integrative Business and Economics Research. Vol 4(1):121-133

Munawaroh, Siti. 2009. Analisis Hubungan Karakteristik dan Kepuasan Pasien dengan Loyalitas Pasien di RSUA dr. Sutomoponorogo. Fakultas Ilmu Kesehatan, UNMUH Ponorogo

Fika Edya (2017) bahwa Cost Recovery Rate untuk pasien rawat inap

Sulastomo.(2002). Asuransi Kesehatan Sosial, PT Raja Grafindo Persada, Jakarta. Thabrany.(1998). Penetapan
Simulasi Tarif Rumah Sakit, disampaikan pada Pelatihan RSPAD November 2008.Jakarta.

Thabrany.H(2014). Jaminan Kesehatan Nasional. PT Raja Grafindo Persada, Jakarta.

Trisnantoro, L. (2009), Memahami

Penggunaan Ilmu Ekonomi

Dalam Manajemen Rumah

Sakit,Yogyakarta: Gajah Mada University Press

Wibowo, A. (2014). Metodologi

Penelitian Praktis Bidang

Kesehatan, PT Raja Grafindo

Persada, Jakarta.

Firmanda, D. (2015). Penyusunan Clinical Pathway, disampaikan pada seminar Clinical Pathway dalam kerangka implementasi INA-CBG's di Ruang Apung Perpustakaan Pusat Universitas Indonesia, Depok, 26 Februari 2015.

Gani, A. 1996. "Analisis Biaya Rumah Sakit Makalah Seri Manajemen Keuangan PelayananKesehatan,Jakarta

Hartono, B. (2005). Tarif Pelayanan dalam Manajemen Pemasaran Untuk Rumah Sakit, Rineka Cipta, Jakarta.

Hosizah. (2013). CaseMix Upaya Pengendalian Biaya Pelayanan Rumah Sakit di Indonesiadiunduh pada

http://www.esaunggul.ac.id/article/ case-mix-upaya- pengendalian-biayarumah-sakit-di-indonesia.

Murti,B. (2000). Dasar-Dasar Asuransi Kesehatan, Canisius, Y ogyakarta.

Sulastomo. (2002).Asuransi Kesehatan Sosial, . Penetapan Simulasi Tarif Rumah Sakit, disampaikan pada Pelatihan RSPAD November 2008. Jakarta.

Thabrany.H(2014). Jaminan Kesehatan

Nasional. PT Raja Grafindo

Persada,Jakarta.

Trisnantoro, L. (2009), Memahami Penggunaan Ilmu Ekonomi Dalam Manajemen RumahSakit, Yogyakarta: Gajah Mada University Press

Wibowo, A. (2014). Metodologi Penelitian Praktis

Bidang Kesehatan, PT Raja Grafindo

Persada, Jakarta. 
Supartiningsih S (2017). Kualitas Pelayanan dan Kepuasan Pasien Rawat Jalan di Rumah Sakit

Sarila Husada Sragen. Jurnal Medicoeticolegal dan Manajemen Rumah Sakit. 2017;6(1):9-15

Rangkuti, Freddy. 2013. Teknik Mengukur dan Strategi Meningkatkan Kepuasan Pelanggan. Gramedia Pustaka Utama, Jakarta

Gerson, R. F.2002. Mengukur Kepuasan Pelanggan : Panduan Menciptakan Pelayanan Bermutu. Jakarta : Penerbit PPM

Wigati, Putri Asmita. 2008. Analisis Pengaruh Persepsi Pasien Tentang Mutu Pelayanan Dokter Terbadap Loyalitas Pasien di Poliklinik. Umum Instalasi Rawat Jalan Rumah Sakit Panti Wilasa Citarum Semarang Tabun 2008. eprints.undip.ac.id 